SEAN MALLETT

\title{
$R v$ Cunnard: JUDICIAL APPLICATION AND EXPANSION OF SECTION 102 OF THE SENTENCING ACT 2002
}

Submitted for the LLB (Honours) Degree

Faculty of Law

Victoria University of Wellington

2013 
Section 102 of the Sentencing Act 2002 gives judges' only limited discretion when sentencing for stage-1 murder: the discretion to rebut the presumption of life imprisonment in circumstances where the sentence would otherwise be "manifestly unjust". This is a high threshold, and the Court of Appeal has said that it will be met only in exceptional cases. The judgment in $\mathrm{R} v$ Cunnard is the first time that a person who derived their conviction of murder from a principal offender has had the presumption displaced, and this essay explores whether or not this decision has lowered the threshold to establish manifest injustice. Although Miller J's judgment conforms to the common features that exist in the few cases where the presumption has been successfully displaced, it is not without criticism. There are issues as to whether an overall assessment of the circumstances of the offence and the offender were made, as well as significant concerns regarding the emphasis the judge placed on sentence parity between co-offenders.

Key words: murder, Sentencing Act, section 102, manifestly unjust, life imprisonment 


\section{Introduction}

Trying a case is as easy as falling off a log. The difficulty comes in knowing what to do with the accused once they have been found guilty. ${ }^{1}$

Sentencing is a critical, yet inherently complex, component of the criminal justice process. While clear statutory direction from the legislature underpins the trial and conviction of an offender, with guilt turning on whether evidentiary thresholds are met, the application of a sentence is inherently discretionary.

This essay will analyse some of the inherent difficulties in sentencing for murder through an extended case study of $R v$ Cunnard. ${ }^{23}$ Cunnard was convicted of murder as a party, but received a sentence of only 10 years imprisonment with no minimum period of non-parole. The sentencing regime for murder encompasses several sections within the Sentencing Act 2002, ${ }^{4}$ but begins with s 102 where there is a legal presumption requiring a court to impose a sentence of life imprisonment unless such a sentence would be manifestly unjust. ${ }^{5}$ The sentencing judge, Miller J, rebutted the presumption and held that it would be manifestly unjust for Cunnard to receive life imprisonment.

Utilising the legislative history and previous case law pertaining to s 102 , this essay will examine whether the decision in $R v$ Cunnard conforms to the previously developed criteria as to what constitutes manifest injustice. Discussion will specifically centre on how the courts have approached the principles and purposes of sentencing found under ss 7 and 8, as well as the relevance and weight given to mitigating factors when there are no significant personal aggravating factors. The essay will also discuss the difficulties of achieving parity in sentencing when dealing with co-offenders and how this prejudiced Miller J's analysis, as well as wider issues relating to judicial discretion when sentencing for murder. Such an examination will allow for a consideration as to whether the decision in $R v$ Cunnard was justified and what ramifications, if any, it has for future s 102 cases.

\footnotetext{
${ }^{1}$ Geoff Hall Sentencing: 2007 Reforms in Context (Lexis Nexis, Wellington, 2007) quoting McArdle J, at 1.

${ }^{2} R$ v Cunnard [2012] NZHC 815.

${ }^{3}$ This case is also referred to in judgments as $R v$ McNaughton, after the principal offender.

${ }^{4}$ All statutory references henceforth will be to the Sentencing Act 2002, except if otherwise stated.

${ }^{5}$ The sentencing regime is different if the murder is a stage- 2 or stage- 3 offence under $s 86 \mathrm{E}$ of the Sentencing Act 2002. This essay focusses exclusively on s 102, which is triggered if the murder is a stage- 1 offence.
} 


\section{II $R v$ Cunnard: Facts and Procedural History}

On 14 November 2009, Troy Minto was shot and killed at Branford Park on the outskirts of Nelson. Blair McNaughton fired the weapon and was charged and convicted of murder by a jury in the Nelson High Court. Blake Cunnard supplied the firearm and was convicted of murder as a party under s 66(2) of the Crimes Act $1961 .^{6}$

The underlying tension which sparked the confrontation that ultimately led to Minto's death lay between two people: Mr Warren and Mr Proctor. Cunnard's involvement began subsequent to an initial confrontation which had occurred between the Warren and Proctor groups at the Motueka drag races. Although this preliminary confrontation was not physical in nature it acted as a catalyst for the two parties to arrange a fight, where Warren and Procter were to engage in a one-on-one brawl.

The fight was organised to be a fist fight only; this is what both sides saw as the "rules of the street". 7 However, given the inherent distrust between the two groups, both sides opted to bring weapons. These included baseball bats, knuckle dusters and a jemmy bar; Cunnard was the only person to bring a firearm. He was collected by Warren and McNaughton shortly before the fight, where he brought along a golf bag containing a shotgun and a .22 rifle. Cunnard loaded the weapon in anticipation of the altercation.

Whilst waiting for the Proctor group to arrive, the Warren group discussed strategy. Miller J was satisfied that this planning extended to the use of the gun, and added that it would be "inconceivable that so lethal, so exceptional a weapon would be loaded and taken with no discussion about how it might be put to work". ${ }^{8}$ He accepted, however, that the gun was not brought along with any express intention to shoot anyone, and would instead be used only to intimidate the Proctor group should things go wrong.

During the altercation itself Cunnard did not immediately participate in the fighting. McNaughton and Cunnard only stepped forward when they saw one of their associates fall to the ground after taking a heavy blow to the head with a baseball bat. The aggressor with the bat told them to stay back, and it was at this point that Cunnard

\footnotetext{
${ }^{6}$ See appendix.

${ }^{7}$ At [11].

${ }^{8}$ At [15].
} 
removed the firearm from the vehicle and pointed it at the Proctor group. Miller $\mathbf{J}$ accepted that this was done to warn them off.

After a brief period of continued fighting, McNaughton took the gun from Cunnard. There was a transitory stand-off between McNaughton and Minto, and the latter then charged forward. He was shot from a distance of three metres. The wound was fatal.

\section{The Role of Section 102 in Sentencing for Murder}

\section{A Legislative and Statutory Foundations}

Section 102 of the Sentencing Act 2002 creates a presumption in favour of life imprisonment for murder, and is to be read in conjunction with s 172 of the Crimes Act 1961. ${ }^{9}$ The section reads:

\section{Presumption in favour of life imprisonment for murder}

(1) An offender who is convicted of murder must be sentenced to imprisonment for life unless, given the circumstances of the offence and the offender, a sentence of imprisonment for life would be manifestly unjust.

(2) If a court does not impose a sentence of imprisonment for life on an offender convicted of murder, it must give written reasons for not doing so.

(3) This section is subject to section $86 \mathrm{E}(2)$.

If the murder is a stage- 2 or stage- 3 offence then s $86 \mathrm{E}$ is triggered, and the judge's discretion as to whether or not to apply a life sentence is removed. The presumption under $\mathrm{s} 86 \mathrm{E}(2)(\mathrm{b})$ is that the sentence will be served without parole.

According to the Law and Order Select Committee, the manifestly unjust provision was only intended to target a very small group of people. Examples given by the Committee of when the presumption of life imprisonment might be displaced included cases of mercy killings, failed suicide pacts and in situations where the offender is considered a 'battered defendant'. These same examples were later given by the Ministry of Justice in a report which canvassed how judicial sentencing practises had changed after the

\footnotetext{
${ }^{9}$ See appendix.
} 
introduction of the Sentencing Act. ${ }^{10}$ During the first reading of the Bill, the Minister of Justice said that the inclusion of a rebuttable presumption in s 102 would reduce the likelihood that a jury, in order to compensate for a lack of flexibility at sentencing, ${ }^{11}$ would return a verdict of manslaughter rather than murder.

Once the court considers it manifestly unjust to impose a life sentence and accordingly rebuts the presumption, the full range of sentencing options under the Sentencing Act become available. $^{12}$ The court will therefore have recourse to any sentence it thinks appropriate to fulfil the principles and purposes of sentencing. ${ }^{1314}$ It also triggers the consideration of s 16 of the Sentencing Act, ${ }^{15}$ which requires the sentencing judge to have regard to the desirability of keeping offenders in the community as opposed to in prison, "as far as that is practical and consonant with the safety of the community". ${ }^{16}$

\section{B Common Features of Successful 102 Rebuttals}

The Sentencing Act does not define the expression 'manifestly unjust'. This is consistent with the legislative intent: to give judge's more discretion and flexibility when dealing with an offender, ${ }^{17}$ allowing them to impose a sentence which better reflects the variety of factors that can arise in an individual case, and in turn dispensing with "rigid and arbitrary distinctions". ${ }^{18}$ It is therefore necessary to turn to the common law and examine how the judges have approached, interpreted, and applied the provision. An analysis of the common features present in cases where the s 102 presumption has been successfully rebutted gives an insight into what issues and principles judges give weight to when deciding what constitutes manifest injustice. These common features can then be compared with the facts of Cunnard, providing a yard stick against which Miller J's judgment can be measured.

\footnotetext{
${ }^{10}$ Rajesh Chhana and others 'The Sentencing Act 2002: Monitoring the First Year' (Ministry of Justice, March 2004).

${ }^{11}$ The Criminal Justice Act 1985 made life imprisonment for murder mandatory. The sentencing judge had no discretion to impose a lesser sentence.

${ }^{12} R v$ Law (2002) 19 CRNZ 500 at [52].

${ }^{13}$ See appendix for the hierarchy of sentences and orders available under section $10 \mathrm{~A}$ of the Sentencing Act 2002.

${ }^{14}$ See appendix for the full list of the principles and purposes of sentencing.

${ }^{15}$ Which previously would have been irrelevant due to the application of section 16(3)(a), see appendix.

${ }^{16}$ Sentencing Act 2002, s 16(1).

17 (14 August 2001) 594 NZPD 10910.

${ }^{18}$ Chhana 'The Sentencing Act 2002: Monitoring the First Year', above $n 10$ at [54].
} 


\section{Strong Mitigating Factors and No Significant Personal Aggravating Factors}

Section 102 requires the court to assess the circumstances of the offence and the offender, which in turn requires an analysis of the applicable aggravating and mitigating factors set out under ss 9(1) and 9(2) respectively. All of the cases in which the presumption of life imprisonment has been successfully rebutted have been characterised by the presence of strong mitigating factors, and no significant personal aggravating factors.

The defendants in $R v$ Wihongi and $R v$ Rihia both suffered from a long history of abuse at the hands of their victims, and both suffered from significant cognitive impairment. ${ }^{19}$ When sentencing Rihia, Toogood J commented that "the violence of your relationship is demonstrated by the 36 incidents between [the victim] and you attended by Police over the period of 11 years, ${ }^{, 20}$ which resulted in what the clinical psychologist described as a complex post-traumatic stress disorder. ${ }^{21}$ Wihongi was characterised as a 'battered defendant', having been abused and raped by her de facto partner and members of his gang on numerous occasions. Note that offending involving a battered defendant was one of the situations in which the Law and Order Select Committee thought it was appropriate for the s 102 presumption to be displaced.

The Select Committee mentioned also mentioned cases of mercy killings, which was the primary mitigating factor in $R v L a w$. This was a case where the accused was convicted of murdering his wife who had been suffering from Alzheimer's disease, in pursuance of a previous pact they had made whereby they promised to "do each other in" 22 should either of them fall victim to the illness. In this sense the defendant was acting out of compassion, not malice, ${ }^{23}$ with the sentencing judge accepting that he had "acted with the best of motives in the situation as [he] saw it". ${ }^{24}$ While there did exist serious aggravating factors in this case, namely the premeditation and vulnerability of the victim, Randerson $\mathrm{J}$ felt that these were far outweighed by the mitigating factors, which

\footnotetext{
${ }^{19} R v$ Wihongi [2012] 1 NZLR 755; $R$ v Rihia [2012] NZHC 2720.

${ }^{20}$ At [16].

${ }^{21}$ At $[20]$.

${ }^{22}$ At [4].

${ }^{23}$ At [47].

${ }^{24}$ At [44].
} 
also included the offenders guilty plea, previous good character and remorse. ${ }^{25}$ In any event, these are aggravating factors relating to the offence, not the offender.

Premeditation was also an aggravating factor in $R v$ Nelson, ${ }^{26}$ a case concerning a 13 year old boy who shot the partner of his caregiver in the back of the head. But again the Court displaced the presumption of life imprisonment partly on the basis of a number of mitigating factors: a deficiency in decision-making abilities and an inability to process information, ${ }^{27}$ a turbulent family situation, the dynamics of which contributed to the killing, ${ }^{28}$ and youth. ${ }^{29}$ The latter was of particular importance, with Heath $\mathrm{J}$ stating that he "does not see that society's interests are enhanced in any way by sentencing a 13 year old boy to life imprisonment". 30

There were no personal aggravating factors relating to Cunnard, ${ }^{31}$ in contrast to a myriad of mitigating factors: the absence of any "material criminal history", ${ }^{32}$ indicative of his previous good character; his acceptance of responsibility and extensive remorse; a willingness to co-operate with Police; and the difficult family circumstances of his childhood, which were a catalyst for a drug and alcohol dependency. Miller J also gave particular weight to Cunnard's involvement in a restorative justice conference with the victim's family, noting that he was the only offender to have done so. ${ }^{33}$ Participation in such a conference has also been conferred particular importance by the legislature with its inclusion as a principle of sentencing under s $8(\mathrm{j})$, any positive result of which must be taken into account by the judge.

Although the mitigating factors relating to Cunnard are not uniquely compelling, nor can they be characterised as falling under one of the situations mentioned by the Law and Order Select Committee, they were nevertheless sufficient to assist in displacing the presumption. Indeed, Miller $J$ specifically cited the mitigating factors as being one of

\footnotetext{
${ }^{25}$ At [53].

${ }^{26} R$ v Nelson [2012] NZHC 3570.

${ }^{27}$ At [37].

${ }^{28}$ At [8] - [9] and [44].

${ }^{29}$ At [38]

${ }^{30}$ At [50].

${ }^{31} R \cup$ Cunnard, above $\mathrm{n} 2$, at [67].

${ }^{32}$ At [68].

${ }^{33}$ At [57].
} 
the reasons life imprisonment would be disproportionately severe. ${ }^{34}$ This was seen to be appropriate, given the peripheral involvement and limited culpability of Cunnard in the first place. On this ground Miller J's judgment is consistent with previous authority.

\section{Accepted Responsibility and Demonstrated Remorse}

A key feature that runs through most of the cases which displace the presumption of life imprisonment is the offender's acceptance of responsibility for the offending and a demonstration of significant remorse, ${ }^{35}$ the former of which is codified under $\mathrm{s} 7(1)(\mathrm{b})$ as a purpose of sentencing. A guilty plea is one way this can be conveyed. ${ }^{36}$ The Court in $R v$ Rihia noted that: ${ }^{37}$

You recognise your responsibility for what happened, and pleading guilty to murder - knowing that you faced the prospect of life imprisonment - was in many respects courageous, and a significant step on the path to rehabilitation.

A guilty plea was also present in $R v$ Law, but in that case the judge also noted the defendant's serious attempt at taking his own life. ${ }^{38}$ This was a demonstration of the offender's substantial remorse, supported by the judge's comment that "the loss of your wife is a greater penalty for you than anything I can impose". ${ }^{39}$ An attempt at suicide after the commission of the offence was likewise a feature of $R v$ Reid, ${ }^{40}$ with Brewer $\mathrm{J}$ noting that the defendant had been horrified by his actions. ${ }^{41} R v$ Reid is also unique in that the offender confessed to the crime, a confession without which the crime would not have been discovered.

Cunnard's acceptance of responsibility as well as his demonstrated remorse is consistent with these other cases in which life imprisonment has been held to be manifestly unjust. Following his arrest on the night of the offending he provided a full and frank statement to the Police regarding what happened and his role in the events. Although he did not

\footnotetext{
${ }^{34}$ At [69].

${ }^{35} R v$ Nelson is the only exception, but this could be due to the notable youth of the defendant.

${ }^{36}$ The presence of a guilty plea also has wider significance at sentencing for policy reasons, and can warrant a discount in sentence of up to 25 per cent, see Hessell $v R$ [2011] 1 NZLR 607.

${ }^{37}$ At [30].

${ }^{38}$ At $[10]$.

${ }^{39}$ At [44].

${ }^{40} R$ v Reid HC Auckland CRI-2008-090-2203, 4 February 2011.

${ }^{41}$ At [8].
} 
plead guilty to murder, he did plead guilty to manslaughter, which is understandable given his peripheral involvement in the offence. Cunnard also participated in a restorative justice conference with the victim's mother and brother prior to sentencing, with Miller J noting that he was the only offender to have done so, and with the family indicating that he was the only one to treat them with respect throughout the criminal justice process. ${ }^{42}$ This, according to the judge, highlighted the depth of Cunnard's genuine remorse for what happened. ${ }^{43}$

\section{The Need to Protect the Community as an Overriding Purpose}

Protecting the public from an offender is often considered an overriding purpose of the courts, ${ }^{44}$ despite its equal statutory status next to the other purposes of sentencing listed under s 7. ${ }^{45}$ Professor Geoff Hall has suggested that "the goal of sentencing is the protection of society and the purposes of sentencing listed in $\mathrm{s} 7$ are the means by which this is achieved," 46 which is consistent with comments made by the judiciary. For example, the English Court of Appeal in $R v$ Howells held that "courts should always bear in mind that criminal sentences are in almost every case intended to protect the public". 47

This emphasis placed on protection is also seen in the New Zealand case law concerning $\mathrm{s}$ 102. The High Court in $R v$ Mikaele grappled with the perceived conflict between a defendant's culpability - which had been reduced due to an early guilty plea, remorse and diminished intellectual capacity - and the need for public safety. ${ }^{48}$ Harrison $\mathrm{J}$ concluded that "as much as [he] would like to extend the hand of mercy to the [defendant], ${ }^{49}$ it would not be manifestly unjust to impose life imprisonment on the basis that "without formal and intensive supervision, there is a strong risk that [the defendant] would commit the same or a similar crime within a short period". 50 This indicates that the need to protect the community from an offender is the overriding consideration when assessing whether to rebut the presumption in $\mathrm{s} 102$, seemingly

\footnotetext{
${ }^{42}$ At [33].

${ }^{43}$ At [57].

${ }^{44}$ Sir Bruce Robertson (ed) Adams on Criminal Law - Sentencing (online looseleaf ed, Brookers) at [SA7.06].

${ }^{45}$ Sentencing Act 2002, s 7(1)(g).

${ }^{46}$ Geoff Hall, Sentencing Law and Practice (LexisNexis, Wellington, 2004) at [SA7.1].

${ }^{47} R v$ Howells [1999] 1 Cr App R 98 at [104].

${ }^{48} R$ v Mikaele HC Auckland T013638, 30 August 2002.

${ }^{49}$ At [71].

${ }^{50}$ At [71].
} 
confirmed at para [80] where Harrison J noted that "ultimately, when weighing all the principles and factors in balance, I am satisfied that the need to protect the public must prevail”.

Similar overriding emphasis was given to $\mathrm{s} 7(1)(\mathrm{g})$ by Brewer $\mathrm{J}$ in $R v$ Reid. ${ }^{51} \mathrm{Mr}$ Reid was found guilty of murdering his 84 -year-old neighbour. At the time she was killed Reid was suffering from major depression and psychotic delusions, believing that the victim was spying on him. Brewer $\mathrm{J}$ held that Reid would not have committed the murder but for this illness, and that he had since been receiving treatment which had improved his mental condition significantly. He therefore found that Reid no longer posed a risk to himself or others, which was one of the primary reasons why he held that a life sentence would be manifestly unjust under s 102, sentencing Reid instead to 10 years imprisonment.

The weight these two cases place on protecting the community from the offender is such that $\mathrm{s} 7(1)(\mathrm{g})$ almost becomes a preliminary test when considering whether a life sentence is manifestly unjust. Only if the court considers that public safety is not at risk will it move on to consider more broadly the circumstances of the offence and the offender in an overall assessment. However the converse is not true: if there is no risk to the community, this by itself is not enough to rebut the s 102 presumption. Randerson $\mathrm{J}$ in $R v$ Law said that although the defendant posed no danger to the community, "that is not the only matter to be considered". 52 In other words, the s 102 presumption will never be rebutted if there is a risk to public safety, but if there is no risk then the presumption still stands and an analysis of the circumstances of the offence and the offender is necessary.

This approach is consistent with the approach undertaken by Miller $\mathrm{J}$ when sentencing Cunnard. The judge noted that Cunnard's probation officer had assessed him as being at a low risk of reoffending, ${ }^{53}$ and backed this up implicitly by referring to his remorse ${ }^{54}$ and his peripheral role in the altercation. ${ }^{55}$ While it was mentioned that Cunnard

\footnotetext{
${ }^{51} R$ v Reid, above $\mathrm{n} 40$.

${ }^{52} R \cup$ Law, above $\mathrm{n} 12$, at [62].

${ }^{53}$ At [56].

${ }^{54}$ At [57] and [68].

${ }^{55}$ At [65].
} 
suffered from a traumatic brain injury in his youth which resulted in behavioural changes and eventually an abuse of drugs and alcohol, ${ }^{56}$ Miller J gave this little weight, because unlike in Reid and Mikaele, these were peripheral problems that were not material contributing factors to the commission of the offence. Once it was decided that the protection of the community was not at issue, discussion turned to the other applicable purposes and principles of sentencing in order to decide whether to rebut the s 102 presumption, which is again consistent with the approach taken in Law.

\section{The Imposition of a Life Sentence is Not Necessary for General Deterrence}

Deterrence is a "well-entrenched principle which has been widely recognised and relied upon in sentencing practise, ${ }^{, 57}$ having been codified as a purpose of sentencing under $\mathrm{s}$ 7(f). However the importance of deterrence in murder cases where the $\mathrm{s} 102$ presumption is at issue has been held to be limited. In $R v$ Wihongi the Court said: ${ }^{58}$

\footnotetext{
We do not see the sentencing principle of deterrence of others as having a major impact on decisions under s 102. By definition, cases involving the consideration of the appropriateness of life imprisonment are exceptional cases where there are significant factors (usually personal to the offender) mitigating the culpability of the offender, calling into play other sentencing principles, particularly rehabilitation.
}

This indicates that although general deterrence is not irrelevant, it is subordinate to other more relevant principles when grappling with s 102. This is consistent with the approach taken in $R v$ Law, where the Court acknowledged that it would be "sending the wrong message to the community if it were prepared to allow the deliberate killing of someone suffering from such a disease or other affliction to go unpenalised." 59 Nevertheless the Court held that general deterrence could be achieved without recourse to a sentence of life imprisonment.

On this basis Miller J's imposition of a sentence less than life is consistent with other cases which have held general deterrence to be of limited importance. Despite stating

\footnotetext{
${ }^{56}$ At [56].

${ }^{57}$ Robertson, above $n$ 44, at [SA7.05].

${ }^{58}$ At [93].

${ }^{59}$ At [62].
} 
that general deterrence requires a stern sentence to be imposed, ${ }^{60}$ he nonetheless acknowledged that Cunnard was not the principal offender and his involvement in the offence was peripheral. For the quantum of his sentence to reflect the need deter murder generally would be disproportionate to his participation and culpability: a more appropriate purpose of denunciation in Cunnard's case would be to (1) prevent people from engaging in group violence, and (2) prevent people from brandishing loaded firearms. Although these alternative general deterrence purposes were not made explicit by Miller J, his imposition of a sentence less than life suggests that deterring people from murder generally was not a primary consideration, and that it was given only little attention in the overall analysis.

\section{Overarching Need for an Overall Assessment}

Although Cunnard is consistent with various individual features of previous successful s 102 cases, the Court of Appeal in $R v$ Rapira has said that manifest injustice "is a conclusion likely to be reached in exceptional cases only," ${ }^{, 61}$ and that the analysis must be undertaken in light of the principles and purposes of sentencing set out in ss 7,8 and 9 of the Sentencing Act. Furthermore, s 102 itself explicitly states that the court must take into account the circumstances of both the offence and the offender, articulated by Elias CJ as requiring an "overall assessment."62 Priestly $\mathrm{J}$ in $R v O^{\prime}$ Brien conveyed similar sentiments, stating that: ${ }^{63}$

\footnotetext{
'Unjust' can only mean that in the context of a particular murder and particular offender, the normal sentence of life imprisonment runs counter to both a Judge's perception of a lawfully just result and also offends against the community's innate sense of justice.
}

The High Court in $R v$ Rawiri explicitly put forward a number of principles that affect the exercise of discretion under s $102,{ }^{64}$ which included the need for the test to be satisfied in light of both the offender and the offence, consistent with the wording of $\mathrm{s}$ 102(1). Fisher $\mathrm{J}$ said that although there might be strong mitigating factors which go towards rebutting the presumption, the circumstances of the offence can preclude

\footnotetext{
${ }^{60}$ At [70].

${ }^{61} R$ v Rapira [2003] 3 NZLR 794 (CA) at [121].

${ }^{62} R$ v Rapira, above $\mathrm{n} 61$, at [121].

${ }^{63} R v$ O'Brien (2003) 20 CRNZ 572 at [19].

${ }^{64} R$ v Rawiri HC Auckland T 014047, 16 September 2002 at [27] - [30].
} 
departure. An analysis of both is necessary. This was further highlighted in $R v$ Mikaele, where Harrison $\mathbf{J}$ noted the difference in wording of s 102 as compared to the Law Commission recommendation, commenting that: ${ }^{65}$

"[t]here is one critical and, I assume, deliberate difference. Parliament substituted the conjunctive 'and' for the disjunctive 'or' in relation to the circumstances of the offence and the offender; they must be considered cumulatively, not the in the alternative".

This is consistent with the legislative intention of the sentencing reforms, which was to allow the "imposition of a sentence by the Court which was appropriate in all the circumstances." 66

Complications can arise however where a judge does not 'practise what they preach'. It is not uncommon for a judge to indicate that an overall analysis will be undertaken, but then focus their discussion and decision exclusively around only one of the aforementioned 'common features'. An overall analysis - at least on the face of the sentencing notes - is not present.

This was the situation in Cunnard. Although Miller J prefaced his sentence by saying, "looking at your case in the round, I have reached the firm view that life imprisonment would be manifestly unjust" ${ }^{\prime 67}$ and formulating his sentencing notes under the headings of 'personal circumstances' and 'aggravating and mitigating factors', the only principle of sentencing that he discussed fully and at any length was the need for parity, which itself is only tangentially related to s (8)(e). Little to no discussion was had around any of the other principles of sentencing listed under $\mathrm{s} 8$.

Miller J does however have statutory support for this approach. Section 31(2) says that "reasons may be given under this section with whatever level of particularity is appropriate to the particular case". When looking at the case in the round, Miller J acknowledged the existence of all the relevant circumstances of the offence and the offender, but only discussed with particularity those which were of particular relevance to the unique facts of the case: that is, parity of sentencing. It would be redundant and

\footnotetext{
${ }^{65} R$ v Mikaele, above $\mathrm{n} 48$, at [40].

${ }^{66}$ Geoff Hall Sentencing Law and Practice, above $\mathrm{n} 46$, at 591.

${ }^{67}$ At [69].
} 
inefficient to force a judge to raise and dismiss every principle and purpose of sentencing listed under ss 7 and 8 , as well as every factor under s 9 , if they are not relevant on the individual facts of the case.

This is further corroborated by s 31(4), a statutory bar which operates to prevent a judge's failure to discuss any principle of sentencing from turning into a ground for appeal. ${ }^{68}$ This however creates linguistic difficulties within the Act. The principles of sentencing listed under s 8 are all individually prefaced by the auxiliary verb 'must' (i.e. "must take into account"), and yet the operation of ss 31(2) and 31(4) gives judges a shield to hide behind if, as was the case in Cunnard, they choose not to discuss them in their judgment. This is contradictory, and it is therefore necessary to read into s 8 an implicit qualifier before each of the principles: that they must be taken into account only if they are relevant to the facts of the case. This would allow irrelevant principles to be ignored, and would mean that relevant yet marginal principles need only be acknowledged by the judge, and not discussed with any particularity as per s 31(2). In this way an overall assessment will be undertaken, satisfying the wording of s 102 and the previous common law direction, despite the bulk of the discussion centring on only one particular issue. In $R v$ Cunnard the particular issue was parity of sentencing.

\section{Party liability and parity of sentencing}

Miller J noted explicitly at para [69] that one of the reasons life imprisonment for Cunnard would be manifestly unjust was due to the sentence imposed on the principal offender, McNaughton. He said that “a party's culpability, or degree of involvement in the offence, may differ greatly from the principal, ${ }^{, 69}$ and referred to ss $8(a)$ and $9(2)$ (d) as statutory authority for taking this into account when imposing a sentence.

McNaughton was sentenced to life imprisonment with a minimum non-parole period of 10 years. ${ }^{70}$ His degree of culpability was significantly higher than Cunnard's, with Miller J noting at para [44] that McNaughton was a leader, "instrumental in arranging the fight, planning [the] group's strategy, and trying to manage the fight as it went on". Furthermore, he was the only person to threaten the other side with the firearm;

\footnotetext{
${ }^{68}$ See appendix.

${ }^{69}$ At [61].

${ }^{70} R$ v Cunnard, above $\mathrm{n} 2$, at [53].
} 
Cunnard in comparison only wielded it in self-defence. When McNaughton did fire the weapon, Miller $\mathrm{J}$ described it as a "deliberate and grossly excessive reaction to the threat [Minto] posed," not to be manifestly unjust.

While it is clear that co-offenders can have different levels of culpability, and as such different sentences, ${ }^{72}$ this is the first time that the court has sentenced a principal offender to life imprisonment while displacing the presumption of life imprisonment for their co-offender on the grounds of manifest injustice. Given that both McNaughton and Cunnard were convicted of murder, such a disparity in sentence may cause issues around the concept of even-handed justice. The Court of Appeal in $R v$ Lawson said that: ${ }^{73}$

[A] marked difference in the sentence imposed on co-offenders, and for which no justification can be shown, may be of importance to the administration of justice generally in that such a marked and unjustified difference will tend to bring the administration of justice into disrepute. The Court must bear in mind that public confidence in the administration of justice is best preserved if justice appears to be administered even-handedly.

Although there is no requirement in law that co-offenders be treated alike, ${ }^{74}$ Miller $\mathrm{J}$ acknowledged the importance of parity at sentencing and the need to treat the sentences imposed on offenders differently where their culpability and circumstances differ materially. $^{75}$

The issue then becomes whether McNaughton was so much more culpable than Cunnard that he should be sentenced to life imprisonment, whereas the latter should only receive 10 years. On the facts such a conclusion seems entirely open and reasonable. As stated above, Cunnard's involvement in the offence extended to bringing the gun (albeit having no intention to use it) and pointing at the Proctor group in selfdefence. He had several opportunities to fire the weapon during the fight, but opted not to, at one stage opting to be assaulted rather than pull the trigger. The only reason he

\footnotetext{
${ }^{71}$ At [44].

72 Police v Egden [1977] 1 NZLR 123 (CA); R v Phillips [1991] 3 NZLR 175 (CA).

${ }^{73} R v$ Lawson [1982] 2 NZLR 219 at [223].

${ }^{74}$ Geoff Hall Sentencing Law and Practice, above $\mathrm{n} 46$, at [2.2.14].

${ }^{75}$ At [64].
} 
was convicted of murder was because of the way s 66(2) of the Crimes Act applies: he joined in the common purpose knowing that the use of the weapon with murderous intent - not necessarily by him, but by any individual there (of whom he has no control over) - was a probable consequence. This, coupled with his personal circumstances and the aforementioned mitigating factors, gives rise to a significantly lower level of culpability than McNaughton. As such, the lower sentence imposed does not stand out as being "unjustifiable or gross," open to a sentencing judge. ${ }^{77}$

However, the need for parity raises other complications. When sentencing Cunnard, Miller J seems to have manipulated the length of imprisonment in order to achieve a parity that represents the parties' respective culpability. In other words, in deciding the quantum of Cunnard's sentence the judge has given disproportionate weight in trying to achieve parity in relation to McNaughton's sentence. It could be argued that in doing so he failed to make the required overall assessment of the circumstances of the offender and offence as stipulated in previous cases and s 102 itself.

There are several aspects of Miller J's judgment that lend credence to this theory. The first is that the minimum period of non-parole imposed can be used as a mechanism to reflect the level of culpability between co-offenders. If two co-offenders are both sentenced under s 102, and the presumption of life imprisonment is not rebutted - which is the situation in the majority of murder cases given the very high threshold of manifest injustice - then the more culpable party will receive a longer non-parole period. This is necessary to satisfy s $86(2) .^{78}$ However, Miller J was unable to reflect Cunnard and McNaughton's respective culpabilities in the imposition of a non-parole period, as $\mathrm{s}$ 103(2) establishes that the non-parole period may not be less than 10 years. Given that he had sentenced McNaughton to a minimum non-parole period of 10 years, the only avenue left for him to distinguish the pairs' determinate sentence, and in turn level of culpability, was by rebutting the presumption under s 102 in relation to Cunnard. It is therefore plausible that a major reason Cunnard did not receive life imprisonment is

\footnotetext{
${ }^{76}$ The level a disparity needs to reach before an appellate court will overturn a sentence, see $R v$ Rameka [1973] 2 NZLR 592 (CA).

${ }^{77}$ Geoff Hall, Sentencing Law and Practice, above n 46, at [5.5.1].

${ }^{78}$ See appendix.
} 
because his sentence would have to have been identical to that of McNaughton, and this would not accurately reflect McNaughton's higher culpability.

What this means is that Miller J gave disproportionate weight to s 8(e) when sentencing: that is, the need for consistency in sentences between similar offenders committing similar offences in similar circumstances. At para [69] he explicitly says that although he has looked at the case in the round, the "dominant consideration" he gave weight to when rebutting the presumption of life imprisonment was parity of treatment. This is going about the analysis in the wrong order. It should never be necessary to give disproportionate attention to parity when deciding on an appropriate sentence, as the sentence reached after making an overall assessment of each individual offender's circumstances and involvement should inherently reflect the different levels of culpability. Section 8(e) should therefore always be satisfied by default after the correct application of the other principles and purposes of sentencing. The Court of Appeal in $R \quad v$ Kohey conveyed similar sentiments, stating that parity is best attained by "sentencing each offender appropriately for his role in the overall offending,"79 taking into account the relevant aggravating and mitigating factors. Miller J merged an analysis of sentencing parity against McNaughton with his analysis of the overall assessment of Cunnard, citing the sentence imposed on the former as a factor for the imposition of a sentence less than life on the latter. In doing so, he is diverting his focus away from the "circumstances of the offence and the offender," which is the explicit legislative direction given under s 102.

On the other hand, there is nothing in the Sentencing Act that prevents Miller $\mathrm{J}$ from placing a disproportionate emphasis on s 8(e). While he must consider all of the principles from (a) to (j), as indicated by the use of the conjunctive "and" at the end of each subsection, he is perfectly entitled to give greater weight to a particular subsection of relevance. Furthermore, there is nothing in the express wording of $\mathrm{s} 8(\mathrm{e})$ which indicates that it should not be taken into account when analysing the circumstances of the offence and the offender. Its fulfilment only as a by-product of the successful application of all of the other principles is logical, and while there is limited common law precedent to back the theory up, it is not explicit in statute. On the face of the

\footnotetext{
${ }^{79} R v$ Kohey (2003) 20 CRNZ 62 at [20].
} 
Sentencing Act it is no different to the other principles of sentencing, and therefore while it must be taken into account, there is not guidance as to when, where and how it should be applied. This is left to the discretion of the judge; a discretion which is on the one hand crucial, but on the other gives rise to a number of wider concerns.

\section{Wider Issues Surrounding Judicial Discretion and Section 102}

The hallmark of the new sentencing regime for murder is its limited flexibility. ${ }^{80}$ Under the Sentencing Act's predecessor, the Criminal Justice Act 1985, the mandatory penalty for a conviction of murder was life imprisonment. The sentencing judge had no discretion to impose a lesser sentence. Now a judge can make use of the narrow "manifestly unjust" provision under s 102 to show leniency in appropriate cases. While this has obvious benefits in that it allows an imposition of a sentence to be made befitting the nature of the crime, there are also inherent risks.

\section{A Benefits of Giving Judges Discretion when Sentencing for Murder}

Discretion is a crucial part of sentencing, as it gives a judge the ability to tailor a sentence appropriate to both the facts of the case and the circumstances of the offender. $^{81}$ Indeed, "individualisation cannot be achieved without a discretion being exercised". ${ }^{82}$ This is especially important in New Zealand because the Crimes Act does not break the offence of murder down into different categories to reflect different levels of culpability. The United States, for example, has categorised homicide into first and second degree murder. ${ }^{83}$ Such a categorisation recognises the fact that the offence of murder catches a broad range of situations, from prolonged torture killings right through to reckless killings and euthanasia. These situations have vastly different levels of culpability and require significantly different sentences to reflect that; but because they are caught by the same section under the Crimes Act the difference in sentence has to be arrived at through judicial discretion. ${ }^{84}$

\footnotetext{
${ }^{80}$ Geoff Hall, Sentencing Law and Practice, above $\mathrm{n} 46$, at [102.1].

${ }^{81}$ Kenneth Davis, Discretionary Justice, A Preliminary Inquiry (Louisiana State University Press, Baton Rouge, 1969) at 17.

82 James L.J. "A Judicial Note on the Control of Discretion in the Administration of Criminal Justice" in Roger Hood (ed) Criminology and Public Policy: Essays in Honour of Sir Leon Radzinowicz, (London, 1974) at 75. 8318 U.S.C $§ 11112010$.

${ }^{84}$ The New Zealand law does differentiate between levels of culpability (measured through one's level of mens rea) that constitute the offence in the first place, but at sentencing these distinctions are lost, because the sentencing judge will often not know which subsection under s 167 the jury found the offender guilty on.
} 
Discretion in sentencing therefore allows the court to give effect to different shades of culpability. In relation to murder, this can be done when imposing the minimum period of non-parole or by rebutting the presumption of life imprisonment itself on the grounds that it would be manifestly unjust under s 102. In Cunnard, judicial discretion is of particular importance given Cunnard derived his liability from the criminal actions of a principal offender. As previously discussed, Cunnard's level of culpability is considerably lower than McNaughton's, despite "being ascribed, alongside [McNaughton], with legal responsibility for the offence". 85 Without sentencing discretion - that is, if the sentence and non-parole periods applied to all people convicted under ss 167 and 168 were fixed - this variation in culpability could not be acknowledged.

A removal of judicial discretion would also have wider implications on the operation of the Sentencing Act. The purposes and principles of sentencing, for example, would become obsolete, as they are inextricably bound together with a discretionary analysis of the individual circumstances of the offence and the offender. The reason for this is clear: it is impossible for the legislature to tailor sentences for every possible fact variation that the Act will apply to.

\section{B Issues with Miller J's Use of Discretion}

Judicial discretion, by its very nature, promulgates inconsistency and uncertainty at sentencing. ${ }^{86}$ This poses a number of problems. It makes it "more difficult for men to plan and conduct their affairs, ${ }^{, 87}$ which is contrary to the rule of law, and it means that a defendant may receive a different sentence depending on which judge he appears before. While the application of s 8(e) of the Sentencing Act requires consistency in sentencing, it must nevertheless be acknowledged that judges are only human, and will analyse a case consistent with their personal beliefs and life experience. Viscount Dilhorne warned that investing magistrates with discretion was "fraught with considerable dangers, ${ }^{, 88}$ and Professor Geoff Hall has said that: ${ }^{89}$

\footnotetext{
${ }^{85}$ A P Simester, W J Brookbanks Principles of Criminal Law (3rd ed, Brookers Ltd, Wellington, 2007) at [6.6.1].

${ }^{86}$ Rosemary Pattenden The Judge, Discretion, and the Criminal Trial (Clarendon Press, Oxford 1982) at 36.

${ }^{87}$ Pattenden, above $\mathrm{n} 94$, at 36.

${ }^{88}$ D.P.P v Humphrys [1970] A.C. 304 at [358].

${ }^{89}$ Geoff Hall, Sentencing Law and Practice, above n 46, at [2.1].
} 
Sentencing is not a rational mechanical process; it is a human process and is subject to all the frailties of the human mind. A wide variety of factors, including the Judge's background, experience, social values, moral outlook, penal philosophy and views as to the merits and demerits of a particular penalty influence the sentencing decision.

Miller J imposed a sentence of 10 years on Cunnard after rebutting the presumption of life imprisonment. Setting aside for one moment the issue as to whether or not the presumption should have been displaced in the first place, a sentence of 10 years is on par with the maximum sentence available for a number offences that are significantly less serious than murder, a crime which has been described by the courts as "the most serious offence in our criminal calendar". ${ }^{9091}$ Miller J explicitly says at para [70] that in a case such as this, if Cunnard had only been convicted of manslaughter, "a starting point may fall within the range of seven to 12 years". Therefore the sentence of ten years imposed by Miller $\mathrm{J}$ is similar, ${ }^{92}$ by his own admission, to a sentence he would impose for manslaughter, and in doing so he fails to give weight to the sentence of murder passed down on Cunnard by a jury of his peers. It could be construed as the judge disagreeing with the conviction given, and in effect replacing it at the sentencing stage.

This is further highlighted by Miller $\mathrm{J}$ at para [57] of his sentencing notes, where he remarks that Cunnard "accept[s] responsibility, while understandably believing that [he] ought to have been convicted of manslaughter". 93 This plainly indicates that Miller J empathised with Cunnard's resentment towards his conviction, and in turn begs the question: was this empathy a factor in the use of judicial discretion to rebut the presumption of life imprisonment under s 102? If it is, then this is plainly an irrelevant consideration that falls outside the purview of the Sentencing Act. Furthermore, it is a use of discretion which undermines the role of the jury in our criminal justice system, and fails to recognise that "juries rule on legal guilt, guilt determined by the highest

\footnotetext{
${ }^{90} R$ v Desai [2012] NZHC 1062 at [22].

${ }^{91}$ For further discussion on the seriousness of murder in the criminal justice system, see Andrew Ashworth Principles of Criminal Law (5th ed, Oxford University Press, Oxford, 2006) at [7.1].

92 The sentence would be similar, but not the equivalent. This is because Miller J specifically says that 7-12 years was only the starting point for manslaughter; any final sentence imposed would therefore be lower. ${ }^{93}$ Emphasis added.
} 
standard of proof we know, beyond a reasonable doubt". 94 It was open to the jury to convict Cunnard of manslaughter, even though his liability was derived from a principal offender who committed murder, ${ }^{95}$ and in rare circumstances the jury can even make a recommendation when giving their verdict to show leniency. ${ }^{96}$ They consciously opted not to. The limited degree of discretion given to judges when sentencing under s 102 was surely not intended to erode the decision of the jury. The discretion exists to be exercised when the sentence, not the conviction, would otherwise be manifestly unjust.

On the other hand, the repercussions that derive from a conviction of murder are wider than simply the number of years one spends imprisoned. The stigma associated with the conviction of murder is a significant punishment in and of itself, something Cunnard will now have to bear for the rest of his life. ${ }^{97}$ So while the rebuttal of the presumption of life imprisonment under s 102 leaves Cunnard with a sentence of 10 years, a sentence which, from a purely numeric standpoint, is indeed on par with offences far less repugnant than murder, the label of murderer and associated stigma subsequently attached to Cunnard forms part of the punishment. Miller J could have been taking this into account when choosing to rebut the presumption. This argument, however, is undermined by the fact that stigma is a societal reaction to the seriousness of murder, and it should not mitigate the term of imprisonment. It is an extra-legal, and indeed abstract, concept, which comes inherently with the conviction. It is therefore not appropriate for the judiciary to take it into account when determining the length of a sentence.

\section{Implications of $R v$ Cunnard}

From the preceding analysis, it is possible to draw two conclusions: (1) despite issues around discretionary emphasis and empathy, Miller $\mathbf{J}$ rebutted the presumption of life imprisonment in a manner consistent with previous case law, and (2) the manifestly unjust provision under s 102 has not been expanded. The "exceptional circumstances" test put forward by the Court of Appeal in $R v$ Rapira continues to apply, ensuring that the threshold to rebut the presumption remains highly restrictive.

\footnotetext{
94 Judge Nancy Gertner "Circumventing Juries, Undermining Justice: Lessons from Criminal Trials and Sentencing" (1999) 32 Suffolk U. L. Rev. 419 at 433.

${ }^{95} R \vee$ Tomkins [1985] 2 NZLR 253.

${ }^{96} R$ v Morgan (1909) 12 GLR 475.

${ }^{97}$ The Criminal Records (Clean Slate) Act 2004 does not apply.
} 
The case could however be seen more generally as an example of how the 'manifestly unjust' provision is being interpreted more liberally than was anticipated by the legislature. It has set a precedent that people who are peripheral secondary parties to an offence can successfully rely on the manifest injustice provision in the same way that a principal offender can. While this is not a revelation in the law, as there was nothing specifically preventing this from occurring before Cunnard, it is another example of a case which differs from the situations put forward by the Law and Order Select Committee: cases of mercy killings, failed suicide pacts, and situations where there is a 'battered defendant'.

On the other hand, that list was never intended to be exhaustive; if it was then those explicitly noted situations would have themselves been codified. The purpose of the section was to create a more flexible sentencing regime, not one built on arbitrary categories, so that the decision a judge comes to will be "appropriate in all the circumstances". ${ }^{98}$ When conceptualised in this way, the decision in $R v$ Cunnard in fact exemplifies the 2002 sentencing reforms in relation to murder. It is a perfect example of how the law has been applied flexibly to ensure a sentence is reached which fits "the nature of the crime and the offender," 99 a situation which could not have been reached under previous sentencing legislation.

Since $R v$ Cunnard, and up until the time of writing, there have been two further cases which have rebutted the presumption of life imprisonment under s 102: $R v$ Rihia and $R$ $v$ Nelson. The former does not mention Cunnard at all, and the latter only mentions it in a footnote as authority for the fact that the s 102 presumption can be rebutted in cases where there is "limited involvement in the offending that gives rise to the crime". 100 Defence counsel for the appellant in Te Wini $v R$ attempted to use Cunnard as authority to claim that the courts have been taking an expansive approach to $\mathrm{s} 102$, but this was immediately dismissed by Wild J, who stated that "the jurisprudence is now fairly settled, and the approach to any departure from the s 102 presumption constrained". ${ }^{101}$ This, however, is poor wording on the part of the judge. It is contradictory for the

98 (14 August 2001) 594 NZPD 10910.

${ }^{99}$ (14 August 2001) 594 NZPD 10910.

${ }^{100}$ At [32].

${ }^{101}$ Te Wini v $R$ [2013] NZCA 201 at [16]. 
section to be both flexible and constrained. Justice Wild must have meant that departure from the presumption is constrained only in the sense that the 'exceptional circumstances' threshold enunciated by the Court or Appeal cannot be lowered. This interpretation is consistent with both the intent of the legislature and previous case authority.

Despite judicial commentary suggesting that the jurisprudence surrounding s 102 is settled, it is still entirely open for a superior court to lower the manifestly unjust threshold. This would be an unlikely step, as it was the current Chief Justice, Dame Sian Elias, who delivered the judgment in $R v$ Rapira which set the threshold so restrictively high in the first place. Even if the judiciary did act to expand s 102 in this way, it would likely provoke a swift response from the legislature, who always sought to "retain a strong presumption in favour of life imprisonment". ${ }^{102}$ This would be consistent with politicians' perennial desire to appear 'tough on crime'. ${ }^{103}$ Parliamentary sovereignty allows any common law extension to be overruled through further legislation which would make the wording of s 102 more explicit.

The Crown has appealed the sentence imposed on Cunnard by Miller J, and a full bench of the Court of Appeal will hear submissions later this year. It is possible that the appellate judges will find fault with the disproportionate emphasis Miller J placed on the need for parity, but it is unlikely this will be enough to quash the sentence. A judge has an inherent degree of discretion when imposing a sentence, and an appellate court must be careful when reviewing a sentence not to substitute its own view of what the sentence should have been, because it fails to give due regard to that discretion. ${ }^{104}$ It is possible that the Court of Appeal will give further guidance on what constitutes manifest injustice for future cases to follow, but this again is unlikely given the number of cross-appeals from the Crown and other co-offenders that need to be dealt with. The Court is more likely to uphold Miller J's decision, and make comments similar to those of Wild J's about the jurisprudence relating to s 102 being settled.

\footnotetext{
102 (14 August 2001) 594 NZPD 10910.

${ }^{103}$ For further discussion of penal populism in New Zealand, see John Pratt and Maria Clarke "Penal Populism in New Zealand" (2005) 73 Punishment and Society 303.

${ }^{104}$ Evans v Bartlam [1937] 2 All ER 646.
} 
Settled, that is, only until the next case comes before the courts which attempts to capitalise on judicial discretion and push the boundaries of what constitutes manifest injustice. How long it will remain the domain of truly 'exceptional cases' is a mystery, but what is clear is that $R v$ Cunnard has done nothing to erode the restrictive nature of $\mathrm{s}$ 102. 


\section{Appendix}

\section{Crimes Act 1961}

\section{Parties to offences}

(2) Where 2 or more persons form a common intention to prosecute any unlawful purpose, and to assist each other therein, each of them is a party to every offence committed by any one of them in the prosecution of the common purpose if the commission of that offence was known to be a probable consequence of the prosecution of the common purpose.

\section{Punishment of murder}

(1) Every one who commits murder is liable to imprisonment for life.

(2) Subsection (1) is subject to section 102 of the Sentencing Act 2002.

\section{Sentencing Act 2002}

\section{Purposes of sentencing or otherwise dealing with offenders}

(1) The purposes for which a court may sentence or otherwise deal with an offender are -

(a) to hold the offender accountable for harm done to the victim and the community by the offending; or

(b) to promote in the offender a sense of responsibility for, and an acknowledgment of, that harm; or

(c) to provide for the interests of the victim of the offence; or

(d) to provide reparation for harm done by the offending; or

(e) to denounce the conduct in which the offender was involved; or

(f) to deter the offender or other persons from committing the same or a similar offence; or

(g) to protect the community from the offender; or

(h) to assist in the offender's rehabilitation and reintegration; or

(i) a combination of 2 or more of the purposes in paragraphs (a) to (h). 
(2) To avoid doubt, nothing about the order in which the purposes appear in this section implies that any purpose referred to must be given greater weight than any other purpose referred to.

\section{Principles of sentencing or otherwise dealing with offenders}

In sentencing or otherwise dealing with an offender the court-

(a) must take into account the gravity of the offending in the particular case, including the degree of culpability of the offender; and

(b) must take into account the seriousness of the type of offence in comparison with other types of offences, as indicated by the maximum penalties prescribed for the offences; and

(c) must impose the maximum penalty prescribed for the offence if the offending is within the most serious of cases for which that penalty is prescribed, unless circumstances relating to the offender make that inappropriate; and

(d) must impose a penalty near to the maximum prescribed for the offence if the offending is near to the most serious of cases for which that penalty is prescribed, unless circumstances relating to the offender make that inappropriate; and

(e) must take into account the general desirability of consistency with appropriate sentencing levels and other means of dealing with offenders in respect of similar offenders committing similar offences in similar circumstances; and

(f) must take into account any information provided to the court concerning the effect of the offending on the victim; and

(g) must impose the least restrictive outcome that is appropriate in the circumstances, in accordance with the hierarchy of sentences and orders set out in section 10A; and

(h) must take into account any particular circumstances of the offender that mean that a sentence or other means of dealing with the offender that would otherwise be appropriate would, in the particular instance, be disproportionately severe; and

(i) must take into account the offender's personal, family, whanau, community, and cultural background in imposing a sentence or other means of dealing with the offender with a partly or wholly rehabilitative purpose; and 
(j) must take into account any outcomes of restorative justice processes that have occurred, or that the court is satisfied are likely to occur, in relation to the particular case (including, without limitation, anything referred to in section 10).

\section{A Hierarchy of sentences and orders}

(1) The hierarchy of sentences and orders set out in subsection (2) reflects the relative level of supervision and monitoring of, and restrictions imposed on, an offender under each sentence or order.

(2) The hierarchy of sentences and orders, from the least restrictive to the most restrictive, is as follows:

(a) discharge or order to come up for sentence if called on:

(b) sentences of a fine and reparation:

(c) community-based sentences of community work and supervision:

(d) community-based sentences of intensive supervision and community detention:

(e) sentence of home detention:

(f) sentence of imprisonment.

\section{Sentence of imprisonment}

(1) When considering the imposition of a sentence of imprisonment for any particular offence, the court must have regard to the desirability of keeping offenders in the community as far as that is practicable and consonant with the safety of the community.

(2) The court must not impose a sentence of imprisonment unless it is satisfied that,-

(a) a sentence is being imposed for all or any of the purposes in section 7(1)(a) to (c), (e), (f), or (g); and

(b) those purposes cannot be achieved by a sentence other than imprisonment; and

(c) no other sentence would be consistent with the application of the principles in section 8 to the particular case.

(3) This section is subject to any provision in this or any other enactment that- 
(a) provides a presumption in favour of or against imposing a sentence of imprisonment in relation to a particular offence; or

(b) requires a court to impose a sentence of imprisonment in relation to a particular offence.

\section{General requirement to give reasons}

(1) A court must give reasons in open court-

(a) for the imposition of a sentence or for any other means of dealing with the offender; and

(b) for the making of an order under Part 2.

(2) The reasons may be given under this section with whatever level of particularity is appropriate to the particular case.

(3) Nothing in this section limits any other provision of this or any other enactment that requires a court to give reasons.

(4) The fact that a court, in giving reasons in a particular case, does not mention a particular principle in section 8 or a particular factor in section 9 or a consideration under section 10 or section 11 is not in itself grounds for an appeal against a sentence imposed or an order made in that case.

\section{Imposition of minimum period of imprisonment in relation to determinate sentence of imprisonment}

(1) If a court sentences an offender to a determinate sentence of imprisonment of more than 2 years for a particular offence, it may, at the same time as it sentences the offender, order that the offender serve a minimum period of imprisonment in relation to that particular sentence.

(2) The court may impose a minimum period of imprisonment that is longer than the period otherwise applicable under section 84(1) of the Parole Act 2002 if it is satisfied that that period is insufficient for all or any of the following purposes:

(a) holding the offender accountable for the harm done to the victim and the community by the offending:

(b) denouncing the conduct in which the offender was involved: 
(c) deterring the offender or other persons from committing the same or a similar offence:

(d) protecting the community from the offender.

(3) [Repealed]

(4) A minimum period of imprisonment imposed under this section must not exceed the lesser of-

(a) two-thirds of the full term of the sentence; or

(b) 10 years.

(5) For the purposes of Part 6 of the Criminal Procedure Act 2011, an order under this section is a sentence. 


\section{Bibliography}

\section{A Texts}

Ashworth, Andrew Principles of Criminal Law (5th ed, Oxford University Press, Oxford, 2006).

Ashworth, Andrew Sentencing and Criminal Justice (4th ed, Cambridge University Press, Cambridge, 2005).

Baker, Dennis Textbook of Criminal Law (3rd ed, Sweet and Maxwell, London, 2012).

Davis, Kenneth Discretionary Justice, A Preliminary Inquiry (Louisiana State University Press, Baton Rouge, 1969).

Hall, Geoff Sentencing: 2007 Reforms in Context (LexisNexis, Wellington, 2007).

Hall, Geoff Sentencing Law and Practice (LexisNexis, Wellington, 2004).

Henham, Ralph Sentencing Principles and Magistrates' Sentencing Behaviour (Gower Publishing Company Ltd, Aldershot, 1990).

Pattenden, Rosemary The Judge, Discretion, and the Criminal Trial (Clarendon Press, Oxford, 1982).

Simester, Andrew and Brookbanks, Warren Principles of Criminal Law (3rd ed, Brookers Ltd, Wellington, 2007).

\section{B Articles}

Gertner, Nancy "Circumventing Juries, Undermining Justice: Lessons from Criminal Trials and Sentencing” (1999) 32 Suffolk U. L. Rev. 419.

Pratt, John and Clarke, Maria "Penal Populism in New Zealand" (2005) 73 Punishment and Society 303.

\section{Other}

Chhana Rajesh and others 'The Sentencing Act 2002: Monitoring the First Year' (Ministry of Justice, March 2004).

Introduction and First Reading of the Sentencing and Parole Reform Bill 2001 (14 August 2001) 594 NZPD 10910.

James L.J. "A Judicial Note on the Control of Discretion in the Administration of Criminal Justice" in Roger Hood (ed) Criminology and Public Policy: Essays in Honour of Sir Leon Radzinowicz, (London, 1974). 
Robertson, Bruce (ed) Adams on Criminal Law - Sentencing (online looseleaf ed, Brookers).

\section{Table of Statutes: New Zealand}

Crimes Act 1961.

Criminal Justice Act 1985.

Parole Act 2002.

Sentencing Act 2002.

\section{E Table of Statutes: United States of America}

18 U.S.C $\S 11112010$.

\section{F Table of Cases: New Zealand}

Hamidzadeh $v R$ [2012] NZCA 550.

Hessell v R [2011] 1 NZLR 607.

Police v Egden [1977] 1 NZLR 123 (CA).

$R v$ Churchward HC Tauranga CRI-2008-270-361, 18 December 2009.

$R v$ Cunnard [2012] NZHC 815.

$R v$ Desai [2012] NZHC 1062.

$R v$ Hamidzadeh HC Auckland CRI-2010-004-19352, 25 August 2011.

$R v$ Kohey (2003) 20 CRNZ 62.

$R v$ Law (2002) 19 CRNZ 500.

$R v$ Lawson [1982] 2 NZLR 219.

$R v$ Mayes [2004] 1 NZLR 71.

$R v$ Mikaele HC Auckland T013638, 30 August 2002.

$R v$ Nelson [2012] NZHC 3570.

$R v$ O'Brien (2003) 20 CRNZ 572.

$R v$ Phillips [1991] 3 NZLR 175 (CA).

$R v$ Rameka [1973] 2 NZLR 592 (CA).

$R v$ Rapira [2003] 3 NZLR 794 (CA).

$R v$ Rihia [2012] NZHC 2720.

$R v$ Rawiri HC Auckland T014047, 16 September 2002.

$R v$ Reid HC Auckland CRI-2008-090-2203, 4 February 2011. 
$R v$ Smail [2007] 1 NZLR 411.

$R v$ Tomkins [1985] 2 NZLR 253.

$R v$ Wihongi HC Napier CRI-2009-041-2096, 30 August 2010.

$R v$ Wihongi [2012] 1 NZLR 755.

Te Wini v R [2013] NZCA 201.

\section{G Table of Cases: United Kingdom}

D.P.P v Humphrys [1970] AC 304.

Evans v Bartlam [1937] 2 All ER 646.

$R v$ Howells [1999] 1 Cr App R 98.

$R v$ Morgan (1909) 12 GLR 475.

\section{H Word Count}

The length of this research paper is 7995 words, excluding abstracts, non-substantive footnotes, appendices and bibliographies. Substantive footnotes amount to 232 words. 